\title{
1,4-dihydropyridine derivatives increase mRNA expression of Psma3, Psmb5, and Psmc6 in rats
}

\author{
Kristīne Dišlere ${ }^{1}$, Evita Rostoka ${ }^{1,2,3}$, Egils Bisenieks $^{3}$, Gunars Duburs ${ }^{3}$, Natalia Paramonova ${ }^{1}$, and \\ Nikolajs Sjakste ${ }^{1,2,3}$
}

${ }^{1}$ University of Latvia Institute of Biology, Riga, Latvia

${ }^{2}$ University of Latvia Faculty of Medicine, Riga, Latvia

${ }^{3}$ Latvian Institute of Organic Synthesis, Riga, Latvia

[Received in April 2020; Similarity Check in April 2020; Accepted in June 2021]

\begin{abstract}
The ubiquitin-proteasome system modifies different cellular and protein functions. Its dysregulation may lead to disrupted proteostasis associated with multiple pathologies and aging. Pharmacological regulation of proteasome functions is already an important part of the treatment of several diseases. 1,4-dihydropyridine (1,4-DHP) derivatives possess different pharmacological activities, including antiaging and neuroprotective. The aim of this study was to investigate the effects of several 1,4-DHP derivatives on mRNA expression levels of proteasomal genes Psma3, Psmb5, and Psmc6 in several organs of rats. Rats were treated with metcarbatone, etcarbatone, glutapyrone, styrylcarbatone, AV-153-Na, or AV-153-Ca per os for three days. mRNA expression levels were determined with real-time polymerase chain reaction (PCR). For AV-153-Na and AV-153-Ca, we also determined the expression of the Psma6 gene. In the kidney, metcarbatone, etcarbatone, styrylcarbatone, and AV-153-Na increased the expression of all analysed genes. Glutapyrone increased the expression of Psmb5 and Psmc6 but did not affect the expression of Psma3. In the blood, glutapyrone increased Psmb5 expression. In the liver, AV-153-Na increased the expression of Psma6 and Psmc6 but lowered the expression of Psmb5, while AV-153Ca only increased Psma6 expression. The ability of 1,4-DHP derivatives to increase the expression of proteasome subunit genes might hold a therapeutic potential in conditions associated with impaired proteasomal functions, but further research is needed.
\end{abstract}

KEY WORDS: AV-153-Ca; AV-153-Na; etcarbatone; gene expression; glutapyrone; impaired proteasomal functions; metcarbatone; pharmacological activities; proteasome subunits; styrylcarbatone; ubiquitin-proteasome system

Proteostasis, or cellular protein homeostasis, relies on the regulation of protein synthesis, folding, conformational maintenance, and degradation (1). Deviations from optimal proteostasis can result in serious pathologies and accelerate the aging of an organism. Proteostasis is maintained by several control systems, all of them of equal importance (1). Protein degradation is partly regulated by the ubiquitinproteasome system (UPS), which ensures rapid and specific turnover of proteins. UPS modifies cellular and protein functions, including cell cycle, cell signalling, DNA repair, chromatin modifications, and protein trafficking (2). These are mediated by ATPase (ubiquitination enzymes encoded by the Psmc genes in rodents) and the $20 \mathrm{~S}$ core particle. The latter has a cylinder-like structure consisting of 28 proteins arranged in four heptameric rings. The outer ring is formed by alpha subunits encoded by the Psma genes in rodents (PSMA in humans). The inner, beta subunits are encoded by the Psmb genes (PSMB in humans) (2). Proteasome gene expression is triggered by the nuclear respiratory factor $1(\mathrm{Nrfl})$. This transcription factor is, in

Corresponding author: Nikolajs Sjakste, University of Latvia Faculty of Medicine, Medical Biochemistry Department, Jelgavas Street 1, LV 1004, Riga, Latvia, E-mail: nikolajs.sjakste@lu.lv turn, regulated by the mammalian target of rapamycin complex 1 (mTORC1) (3) and a feedback mechanism compensating proteasome dysfunction (4). Nrf1-dependent transcription of proteasomal genes is also increased by pharmacological inhibition of proteasomes (2). Pharmacological inhibition of proteasome function is important for the treatment of several diseases such as cancer (5), whereas stimulators of proteasome activity are being researched (6) as potential remedies against neurodegenerative diseases and as antiaging agents. It was shown that proteasome activity in long-living mammal species is higher than in short-living animals (7). Several natural substances were found to stimulate proteasome activity (8), synthetic molecules are also intensively studied (9).

In our opinion, testing of the impact of 1,4-dihydropyridine (1,4-DHP) derivatives, a vast group of compounds with different pharmacological activities, on the UPS could be a prospective research branch. A big group of these compounds has been synthesised in the Latvian Institute of Organic Synthesis over the last few years. Some of them manifest interesting effects besides antioxidant activity (9), as they can modify cell proliferation (10), bind DNA and proteins, or stimulate DNA repair by activating DNA repair 
enzymes $(11,12)$. These novel 1,4-DHP derivatives have a weak $\mathrm{Ca}^{2+}$ channel blocker activity and are water-soluble unlike "classical" $\mathrm{Ca}^{2+}$ channel blockers, which are hydrophobic. Yet they can modify the expression of several genes and proteins $(13,14)$, including the proteasome gene Psma6 (15). The present work aimed to expand our previous research by studying the effects of several 1,4-DHP derivatives on mRNA expression levels of proteasomal genes Psma3, Psmb5, and Psmc6 in several organs of rats to see if they have pharmacological potential as UPS modulators.

\section{MATERIALS AND METHODS}

\section{Animals}

This study was approved by the Animal Ethics Committee of the Food and Veterinary Service (Riga, Latvia) and was carried out according to the guidelines of the 1986 European Convention for the Protection of Vertebrate Animals Used for Experimental and other Scientific Purposes (16). Male Wistar rats $(215.0 \pm 5.6 \mathrm{~g})$ were purchased from the Laboratory of Experimental Animals, Riga Stradins University, Riga, Latvia. Animals were kept at $22 \pm 0.5^{\circ} \mathrm{C}$ with a $12 \mathrm{~h}$ light/dark cycle and fed standard laboratory diet.

\section{Chemicals}

All drugs used in the study - metcarbatone, etcarbatone, glutapyrone, styrylcarbatone (J-9-125), and AV-153 Na and Ca salts (Figure 1) were synthesised at the Latvian Institute of Organic Synthesis. Other chemicals were purchased from Sigma-Aldrich Chemie (Taufkirchen, Germany).

\section{Experimental design}

Rats were divided into control and treatment groups. The latter received $0.05 \mathrm{mg} / \mathrm{kg}$ or $0.5 \mathrm{mg} / \mathrm{kg}$ of metcarbatone, etcarbatone, glutapyrone, styrylcarbatone, AV-153-Na, or AV-153-Ca per os by gavage for three days. The rats were then euthanised and their organ samples (kidneys, blood, and liver) taken and frozen in liquid nitrogen until analysis. There were two sets of rats. Kidneys and blood were taken from the control group (11 animals) and groups treated with metcarbatone, etcarbatone, glutapyrone, and styrylcarbatone (3-4 animals per group). Kidneys and liver were taken from the control group (10 animals) and groups treated with AV$153-\mathrm{Na}$ and AV-153-Ca (3-5 animals per group).

\section{RNA extraction and $c D N A$ synthesis}

Total RNA was isolated from the kidneys, blood, and liver with a TRI reagent (Sigma Aldrich, Taufkirchen, Germany). RNA was purified from DNA with a DNA-free kit (Ambion, Austin, TX, USA) and its quantity and purity determined with a NanoPhotometer ${ }^{\circledR}$ NP80 spectrophotometer (ImplenGMBH, Munich, Germany).

The quality of RNA was analysed with gel electrophoresis. cDNA was synthesised from the obtained RNA ( $5 \mu \mathrm{g}$ from kidneys and liver, and $2 \mu \mathrm{g}$ from blood) with random hexamer primers (RevertAid ${ }^{\mathrm{TM}}$ First Strand cDNA Synthesis Kit, Fermentas, Vilnius, Lithuania).

\section{Real-time reverse-transcription polymerase chain reaction tests}

mRNA expression of Psma3, Psmb5 and Psmc6, and a reference gene (RNA-polymerase II) in the kidney, blood, and liver was determined using the $\mathrm{SYBR}^{\circledR}$ Green PCR Master Mix (Applied Biosystems, Foster City, CA, USA) according to the instructions provided by the manufacturer. For the AV-153-Na and AV-153-Ca treatment groups, we also determined the expression of the Psma6 gene.

Primers were designed using Primer-BLAST software (17). Primer sequences were: Psma3 5'-CACCATCCTCTGGTGTCCATT-3' (forward) and<smiles>CC1=C(C(=O)OCC(=O)O[Na])C(C)(C)C(C(=O)OCC(=O)O[Na])=C(C)N1</smiles>

Metcarbatone<smiles>COC(=O)COC(=O)C1=C(C)NC(C)=C(C(=O)OCC(=O)O[Na])C1/C=C/c1ccccc1</smiles>

Styrylcarbatone<smiles>CCC1(C)C(C(=O)OCC(=O)O[Na])=C(C)NC(C)=C1C(O)OCC(=O)O[Na]</smiles>

Etcarbatone

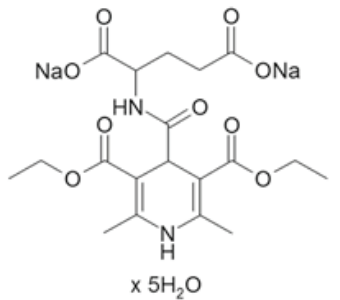

Glutapyrone<smiles>CCOC(=O)C1=C(C)NC(C)=C(C(=O)OCC)C1(C(=O)O)C(=O)O[Na]</smiles>

AV-153-Na
Figure 1 Formulas of 1,4-dihydropyridine derivatives used in the study<smiles>CCOC(=O)C1=C(C)NC(C)=C(C(=O)OCC)C1C(=O)[O-]</smiles>

AV-153-Ca 
Table 1 Kidney and blood real-time PCR cycle threshold $\left(\mathrm{C}_{\mathrm{t}}\right)$ values

\begin{tabular}{|c|c|c|c|c|c|c|c|c|}
\hline & \multicolumn{4}{|c|}{ Kidneys } & \multicolumn{4}{|c|}{ Blood } \\
\hline & RNSpolII & Psma3 & Psmb5 & Psmc6 & RNSpolII & Psma3 & Psmb5 & Psmc6 \\
\hline \multirow{12}{*}{ Control } & 20,6336 & 21,2849 & 20,2966 & 18,5916 & 19,3183 & 24,7317 & 23,9346 & 23,4343 \\
\hline & 19,9632 & 21,0402 & 20,1468 & 18,5301 & 19,1140 & 24,9544 & 23,9330 & 23,6485 \\
\hline & 20,5162 & 20,6843 & 19,9793 & 18,4140 & 19,5568 & 23,5918 & 23,6477 & 22,6171 \\
\hline & 19,7661 & 20,8542 & 20,0899 & 18,4168 & 19,5473 & 25,3724 & 23,5371 & 23,2719 \\
\hline & 20,4493 & 21,1992 & 20,3281 & 18,7329 & 19,2752 & 24,2432 & 23,6730 & 22,2758 \\
\hline & 20,0575 & 20,7519 & 19,8123 & 18,2283 & 18,0247 & 24,1311 & 23,7417 & 21,8996 \\
\hline & 19,8994 & 20,8551 & 20,1670 & 18,5733 & 19,6721 & 24,1230 & 22,6278 & 22,9333 \\
\hline & 19,9792 & 21,2709 & 20,5719 & 18,8297 & 18,5737 & 23,8446 & 23,0603 & 22,4729 \\
\hline & 20,3273 & 21,4559 & 20,4872 & 18,9060 & 18,9473 & 24,8475 & 24,5772 & 23,0626 \\
\hline & 20,7163 & 21,1733 & 20,4132 & 18,8730 & 19,7215 & 24,5549 & 23,4031 & 23,6338 \\
\hline & 20,1879 & 21,1945 & 20,4594 & 18,7461 & 18,7025 & 24,7850 & 24,1693 & \\
\hline & & & & & 18,7703 & 24,3940 & 24,0506 & \\
\hline \multirow{4}{*}{$\begin{array}{l}\text { Metcarbatone } \\
0.05 \mathrm{mg} / \mathrm{kg}\end{array}$} & 21,1421 & 21,1700 & 20,2690 & 18,7102 & 19,1992 & 24,9793 & 24,9819 & 23,4209 \\
\hline & 20,6063 & 20,9449 & 20,0149 & 18,6103 & 18,2122 & 25,0053 & 24,6967 & 22,8411 \\
\hline & 20,9352 & 21,4263 & 20,5656 & 18,9078 & 19,6951 & 24,3028 & 23,8090 & 22,9598 \\
\hline & 20,5415 & 20,9494 & 20,0938 & 18,4946 & 18,7135 & 24,5634 & 24,1763 & 22,6806 \\
\hline \multirow{4}{*}{$\begin{array}{l}\text { Metcarbatone } \\
0.5 \mathrm{mg} / \mathrm{kg}\end{array}$} & 20,8324 & 20,9915 & 20,1140 & 18,8390 & 18,9062 & 25,2567 & 23,8337 & 23,6736 \\
\hline & 21,1187 & 21,0831 & 20,1682 & 18,7917 & 19,2715 & 25,2724 & 24,5450 & 23,6550 \\
\hline & 21,0912 & 21,1248 & 20,3896 & 18,8515 & 18,5728 & 24,6956 & 23,9355 & 22,8742 \\
\hline & 20,6640 & 21,1151 & 20,0875 & 18,7441 & 18,6701 & 25,2925 & 24,5882 & 23,2121 \\
\hline \multirow{3}{*}{$\begin{array}{l}\text { Etcarbatone } \\
0.05 \mathrm{mg} / \mathrm{kg}\end{array}$} & 20,6521 & 21,3114 & 20,2236 & 18,6247 & 18,8542 & 24,8812 & 24,1604 & 22,9606 \\
\hline & 21,2283 & 21,3560 & 20,3069 & 18,6993 & 19,1319 & 24,8758 & 24,7965 & 22,9433 \\
\hline & 21,3387 & 21,4437 & 20,1647 & 18,7293 & 18,1798 & 24,6700 & 24,4486 & 22,5183 \\
\hline \multirow{4}{*}{$\begin{array}{l}\text { Etcarbatone } \\
0.5 \mathrm{mg} / \mathrm{kg}\end{array}$} & 20,6957 & 21,2241 & 20,1316 & 18,4727 & 19,2888 & 24,9479 & 24,4943 & 23,1595 \\
\hline & 21,4283 & 21,6113 & 20,5876 & 18,8926 & 19,2577 & 24,8016 & 24,0260 & 23,0911 \\
\hline & 21,0995 & 21,5415 & 20,3180 & 18,8051 & 18,9519 & 24,5479 & 24,2079 & 22,4058 \\
\hline & 20,9716 & 21,4134 & 20,4994 & 18,8108 & 19,0836 & 24,6532 & 24,6596 & 22,5140 \\
\hline \multirow{4}{*}{$\begin{array}{l}\text { Styrylcarbatone } \\
0.05 \mathrm{mg} / \mathrm{kg}\end{array}$} & 21,4476 & 21,4452 & 20,5627 & 18,6984 & 19,5796 & 23,9558 & 23,0535 & 22,6217 \\
\hline & 20,9010 & 21,0415 & 20,1628 & 18,3986 & 19,0160 & 24,8889 & 24,1739 & 23,2842 \\
\hline & 21,3434 & 21,2509 & 20,2865 & 18,6662 & 18,1215 & 23,5157 & 23,3238 & 21,4245 \\
\hline & 21,6191 & 22,0462 & 21,5846 & 18,9777 & 19,5722 & 25,4267 & 24,9225 & 23,4448 \\
\hline \multirow{4}{*}{$\begin{array}{l}\text { Styrylcarbatone } \\
0.5 \mathrm{mg} / \mathrm{kg}\end{array}$} & 21,5660 & 21,5113 & 21,2236 & 18,9375 & 19,1745 & 23,8688 & 23,2048 & 22,2596 \\
\hline & 21,2131 & 21,5601 & 20,7720 & 18,7713 & 19,5076 & 24,7026 & 23,6100 & 23,0168 \\
\hline & 21,0897 & 21,4685 & 20,4881 & 18,7617 & 18,9420 & 24,6156 & 23,8653 & 23,2664 \\
\hline & 21,4455 & 21,6779 & 20,9215 & 18,9282 & & & & \\
\hline \multirow{4}{*}{$\begin{array}{l}\text { Glutapyrone } \\
0.05 \mathrm{mg} / \mathrm{kg}\end{array}$} & 22,0678 & 22,8544 & 21,6248 & 19,8827 & 18,9078 & 23,7505 & 22,4539 & 22,0790 \\
\hline & 21,0281 & 22,1696 & 20,8820 & 19,3440 & 19,1537 & 23,5877 & 22,7654 & 22,3149 \\
\hline & 21,1787 & 21,9149 & 20,8096 & 19,0287 & 20,1436 & 25,5499 & 23,8626 & 23,8251 \\
\hline & 21,3287 & 21,5062 & 20,4549 & 18,7512 & 19,6614 & 24,1258 & 23,0498 & 23,1506 \\
\hline \multirow{4}{*}{$\begin{array}{l}\text { Glutapyrone } \\
0.5 \mathrm{mg} / \mathrm{kg}\end{array}$} & 21,0105 & 21,8076 & 20,5749 & 18,8806 & 19,3639 & 24,6586 & 23,1130 & 22,9958 \\
\hline & 20,6910 & 21,6908 & 20,2656 & 18,6775 & 19,6876 & 25,6195 & 23,7417 & 24,0393 \\
\hline & 21,1142 & 21,4909 & 20,2270 & 18,7062 & 19,4588 & 24,3839 & 23,1421 & 22,8727 \\
\hline & 21,3715 & 21,4707 & 20,0467 & 18,8292 & 19,4118 & 24,7691 & 23,3703 & 23,2199 \\
\hline
\end{tabular}


5'-CGCAGATATCCTCAATTACCCAAC-3' (reverse) (fragment size 128 bp); Psmb55'-AGGTGCCTACATTGCTTCCC-3' (forward) and 5'-GAGATGCGTTCCTTGTTGCG-3' (reverse) (fragment size 159bp); Psmc6-5'-TACATTGGGGAAAGCGCTCG-3' (forward) and 5'-TCAGAAAACCGACGACCACC-3' (reverse) (fragment size $116 \mathrm{bp}$ ); and Psma6 5'-GTGTGCGCTACGGGGTGTA-3' (forward) and 5'-AGTCACGGTGCTGGAATCCA-3' (reverse) (fragment size $247 \mathrm{bp}$ ). The choice of the reference $R N A$-polymerase II gene was described earlier (18). Primer sequences for this gene were 5'-GCCAGAGTCTCCCATGTGTT-3' (forward) and 5'-GTCGGTGGGACTCTGTTTGT-3' (reverse) (amplified fragment size $135 \mathrm{bp}$ ).

Oligonucleotides were supplied by Metabion International AG (Martinsried, Germany). qPCR reactions were performed using a StepOne ${ }^{\mathrm{TM}}$ Real-Time PCR System (Applied Biosystems, Foster City, CA, USA). Cycling conditions were as follows: one cycle at $95{ }^{\circ} \mathrm{C}$ for $10 \mathrm{~min}$, 40 cycles at $95^{\circ} \mathrm{C}$ for $15 \mathrm{sec}$, and one cycle at $60^{\circ} \mathrm{C}$ for
1 min (Applied Biosystems StepOne software, version 2.1). The specificity of amplification products was verified by dissociation curve: one cycle at $95{ }^{\circ} \mathrm{C}$ for $15 \mathrm{sec}$, one at $60{ }^{\circ} \mathrm{C}$ for $1 \mathrm{~min}$, and one at $95{ }^{\circ} \mathrm{C}$ for $15 \mathrm{sec}$. The cycle threshold $\left(\mathrm{C}_{\mathrm{t}}\right)$ values are presented in Tables 1 and 2 .

\section{Statistics}

Reference gene stability was analysed with BestKeeper provided in RefFinder (https://www.heartcure.com). Among studied organs, standard deviation (SD) values ranged from 0.22 to 0.54 , and the coefficient of variance (CV) ranged from 1.13 to 2.63 . These values are consistent with those reported for stable housekeeping genes (19). Gene expression data were expressed using the $2^{-\Delta \Delta \mathrm{Ct}}$ method mean fold difference with standard error of the mean (SEM) (20). The P values were calculated from delta values using one-way ANOVA followed by Dunnett's test for multiple comparisons between the groups. In all tests, the $\mathrm{P}$ value of $<0.05$ was considered statistically significant. All

Table 2 Liver real-time PCR cycle threshold $\left(\mathrm{C}_{\mathrm{t}}\right)$ values

\begin{tabular}{|c|c|c|c|c|c|c|c|c|c|c|}
\hline & \multicolumn{5}{|c|}{ Kidneys } & \multicolumn{5}{|c|}{ Liver } \\
\hline & RNSpolII & Psma3 & Psmb5 & Psmc6 & Psma6 & RNSpolII & Psma3 & Psmb5 & Psmc6 & Psma6 \\
\hline \multirow{10}{*}{ Control } & 20,5970 & 22,5839 & 19,2551 & 19,1623 & 19,9986 & 19,8560 & 23,0557 & 21,1670 & 18,6385 & 19,8489 \\
\hline & 20,4384 & 22,5746 & 19,0794 & 18,8645 & 19,5620 & 19,5794 & 22,9181 & 21,1984 & 18,6208 & 19,6455 \\
\hline & 20,4358 & 22,5837 & 19,1140 & 18,8865 & 19,7310 & 19,9334 & 23,3011 & 21,1796 & 19,6168 & 20,4226 \\
\hline & 20,5461 & 22,7381 & 19,0685 & 19,1585 & 19,7124 & 19,7203 & 23,1264 & 21,1636 & 19,4941 & 20,2836 \\
\hline & 20,3772 & 22,3517 & 19,0689 & 19,2026 & 20,2427 & 19,1888 & 22,9224 & 21,0717 & 19,1761 & 19,8373 \\
\hline & 20,3640 & 22,2591 & 18,9613 & 18,9177 & 19,7695 & 19,7114 & 23,1850 & 21,1812 & 19,1708 & 20,0905 \\
\hline & 20,4210 & 22,1444 & 19,0667 & 18,8171 & 19,3981 & 19,8140 & 23,5071 & 21,3909 & 19,3937 & 20,2497 \\
\hline & 20,5429 & 22,3808 & & 19,2618 & 20,5558 & 19,7631 & 23,3798 & 21,3486 & 19,0927 & 20,2443 \\
\hline & 20,4095 & 22,3303 & & 18,9823 & 20,3727 & 19,6435 & 23,5475 & 21,2771 & 19,3322 & 20,4155 \\
\hline & 19,9648 & 22,0525 & & 18,7116 & 19,2846 & & & & & \\
\hline \multirow{4}{*}{$\begin{array}{l}\text { AV-153-Na } \\
0.05 \mathrm{mg} / \mathrm{kg}\end{array}$} & 21,1756 & 22,9314 & 19,3199 & 19,5803 & 20,0066 & 19,3193 & 22,6985 & 21,0440 & 18,3758 & 18,9400 \\
\hline & 22,0513 & 23,4752 & 19,6423 & 19,9317 & 20,6172 & 18,8415 & 22,8245 & 20,9705 & 18,3795 & 19,0355 \\
\hline & 21,4856 & 23,2240 & 19,4647 & 19,6623 & 19,8643 & 19,5196 & 22,7070 & 21,0585 & 18,3857 & 19,0187 \\
\hline & 21,6234 & 23,2381 & 19,5993 & 19,5928 & 19,6469 & 18,8631 & 22,7883 & 20,9608 & 18,3031 & 18,9503 \\
\hline \multirow{3}{*}{$\begin{array}{l}\text { AV-153-Na } \\
0.5 \mathrm{mg} / \mathrm{kg}\end{array}$} & 21,9367 & 23,2775 & 19,4898 & 19,8077 & 20,0014 & 19,6059 & 22,7776 & 20,9764 & 18,4171 & 19,0567 \\
\hline & 21,6564 & 23,2385 & 19,5634 & 19,4900 & 19,8338 & 19,6035 & 22,8215 & 21,0093 & 18,4078 & 19,0701 \\
\hline & 21,2077 & 23,2004 & 19,4074 & 19,5859 & 19,9741 & 19,5527 & 22,8589 & 20,9877 & 18,3254 & 19,1177 \\
\hline \multirow{4}{*}{$\begin{array}{l}\text { AV-153-Ca } \\
0.05 \mathrm{mg} / \mathrm{kg}\end{array}$} & 19,7019 & 22,0370 & 19,1800 & 18,7166 & 19,3175 & 19,3393 & 22,9415 & 20,8086 & 19,1408 & 19,8715 \\
\hline & 19,8564 & 22,2813 & 19,3695 & 18,7706 & 19,2143 & 19,6280 & 23,3113 & 21,0154 & 19,1477 & 20,3142 \\
\hline & 20,1111 & 21,8349 & 19,0583 & 18,6593 & 19,3757 & 19,3697 & 22,8512 & 20,9235 & 18,9642 & 20,2187 \\
\hline & & & & & & 19,6506 & 23,1935 & 21,0658 & 19,3068 & 20,0824 \\
\hline \multirow{5}{*}{$\begin{array}{l}\text { AV-153-Ca } \\
0.5 \mathrm{mg} / \mathrm{kg}\end{array}$} & 20,3086 & 22,0432 & 19,5138 & 18,8374 & 19,3591 & 19,4528 & 22,9892 & 20,7577 & 19,0212 & 19,3202 \\
\hline & 20,5201 & 22,7760 & 18,8733 & 19,2125 & 20,2666 & 19,5880 & 23,2170 & 21,2606 & 19,0527 & 19,6300 \\
\hline & 19,5801 & 21,8729 & 18,8382 & 18,7051 & 19,3437 & 18,8662 & 23,0295 & 21,3512 & 18,8270 & 19,3601 \\
\hline & 20,1326 & 22,0602 & 18,9902 & 18,8147 & 19,6876 & 19,5368 & 23,2560 & 21,5740 & 19,0952 & 19,4394 \\
\hline & 20,1226 & 21,8402 & 18,8235 & 18,8101 & 19,4492 & 19,5666 & 23,0126 & 21,1141 & 18,7163 & 19,2355 \\
\hline
\end{tabular}


analyses were run on the GraphPad Prism 6 version 6.01 software (GraphPad Software, San Diego, CA, USA).

\section{RESULTS}

\section{Metcarbatone}

In the kidney, metcarbatone at both doses significantly increased the expression of the Psma3, Psmb5, and Psmc6 genes (Table 3 ). The higher dose produced a more pronounced effect for Psma3 and Psmb5. The increase ranged from 1.43-fold with $P$ smc6 $(0.05 \mathrm{mg} / \mathrm{kg}$ : $\mathrm{P}=0.010$; $0.5 \mathrm{mg} / \mathrm{kg}$ : $\mathrm{P}=0.015)$ to 1.69 -fold with $P s m b 5(0.5 \mathrm{mg} / \mathrm{kg}$ : $\mathrm{P}=0.001)$. In the blood, metcarbatone significantly decreased the Psmc6 gene expression by $0.60(0.5 \mathrm{mg} / \mathrm{kg}$ : $\mathrm{P}=0.032$ ).

\section{Etcarbatone}

The Psma3, Psmb5, and Psmc6 gene expression significantly increased in the kidney (Table 4), from 1.36fold at the higher dose for Psma3 ( $\mathrm{P}=0.046)$ to 1.82 -fold at the lower dose for Psmb5 $(\mathrm{P}=0.002)$. No significant differences were detected in the blood.

\section{Styrylcarbatone}

Styrylcarbatone significantly increased the expression of the Psma3, Psmb5 and Psmc6 genes (Table 5). It was the most pronounced for Psmc6 - up to 2.05-fold at the lower dose $(\mathrm{P}<0.0001)$. No significant differences were detected in the blood.

\section{Glutapyrone}

In the kidney, the higher dose of glutapyrone significantly increased Psmb5 expression 1.73-fold $(\mathrm{P}=0.003$; Table 6) and Psmc6 expression up to 1.59 -fold $(\mathrm{P}=0.004)$. In the blood, the lower dose of glutapyrone increased Psmb5 expression 2.04-fold $(\mathrm{P}=0.036)$.

\section{$A V-153-N a$}

AV-153-Na significantly increased the expression of Psma3, Psmb5, Psmc6, and Psma6 at both doses (Table 7) in the kidney. The higher dose resulted in the highest (2.17fold) increase in Psma6 ( $\mathrm{P}=0.0007)$, while the lower dose increased it 1.91-fold $(\mathrm{P}=0.0002)$. Psmc6 gene expression increased 1.61-fold at the higher dose $(\mathrm{P}=0.017)$, but the lower dose decreased the Psmb5 gene expression by 0.79 $(\mathrm{P}=0.029)$.

\section{$A V-153-C a$}

In the kidney, AV-153-Ca significantly affected only the Psmb5 gene expression, which decreased by 0.62 at the lower dose ( $\mathrm{P}=0.0043$; Table 8$)$. In the blood, Psma6 gene expression increased 1.35-fold at the lower dose. Other tested genes were not affected significantly.

\section{DISCUSSION}

Most of the tested 1,4-DHP derivatives increased gene expression levels in the kidney but were mainly without a significant effect in the blood and liver. The general sensitivity of the kidney cells to 1,4-DHP could simply be explained by accumulation of the compounds in the kidney before excretion, but there are no data to support it.

Comparing the effects of 1,4-DHP derivatives on different proteasome subunit genes, we noticed that subunit mRNA expression did not follow a uniform pattern. Other authors have also reported divergent effects of drugs on different proteasome subunit gene expression. For example, cocaine mainly upregulated the PSMB1 and PSMA5 subunits and downregulated the PSMA6 subunit but did not affect the PSMB2 and PSMB5 subunits (21).

In the kidney, metcarbatone, etcarbatone, styrylcarbatone, and AV-153-Na increased the expression of all analysed genes, but glutapyrone and AV-153-Ca showed varying effects. Glutapyrone did not affect the expression of Psma3, which codes for the outer ring subunit of the $20 \mathrm{~S}$

Table 3 The effect of metcarbatone on Psma3, Psmb5 and Psmc6 gene expression in the kidney and blood

\begin{tabular}{lccc}
\hline \multirow{3}{*}{ Psma3 } & $\begin{array}{c}\text { Metcarbatone } \\
(\mathbf{m g} / \mathbf{k g})\end{array}$ & $\begin{array}{c}\text { Kidney } \\
\text { fold difference (SEM range) }\end{array}$ & $\begin{array}{c}\text { Blood } \\
\text { fold difference (SEM range) }\end{array}$ \\
\cline { 2 - 4 } & Control & $1.00(0.93-1.07)$ & $1.00(0.87-1.14)$ \\
\hline \multirow{3}{*}{ Psmb5 } & 0.05 & $1.44(1.34-1.54)^{*}$ & $0.76(0.56-1.04)$ \\
\cline { 2 - 4 } & 0.50 & $1.61(1.50-1.74)^{* *}$ & $0.53(0.48-0.58)$ \\
\hline \multirow{3}{*}{ Psmc6 } & Control & $1.00(0.93-1.08)$ & $1.00(0.84-1.18)$ \\
\cline { 2 - 4 } & 0.05 & $1.51(1.40-1.63)^{* *}$ & $0.55(0.39-0.77)$ \\
\cline { 2 - 4 } & 0.50 & $1.69(1.60-1.79)^{* *}$ & $0.58(0.51-0.67)$ \\
\hline & 0.05 & $1.00(0.94-1.07)$ & $1.00(0.90-1.12)$ \\
\hline
\end{tabular}

$* \mathrm{P}<0.05$ and $* * \mathrm{P}<0.01$ compared to control 
Table 4 The effect of etcarbatone on Psma3, Psmb5 and Psmc6 gene expression in the kidney and blood

\begin{tabular}{lccc}
\hline \multirow{3}{*}{$\begin{array}{c}\text { Etcarbatone } \\
(\mathbf{m g} / \mathbf{k g})\end{array}$} & $\begin{array}{c}\text { Kidney } \\
\text { fold difference (SEM range) }\end{array}$ & $\begin{array}{c}\text { Blood } \\
\text { fold difference (SEM range) }\end{array}$ \\
\cline { 2 - 4 } & Control & $1.00(0.93-1.07)$ & $1.00(0.87-1.14)$ \\
\cline { 2 - 4 } & 0.05 & $1.46(1.29-1.65)^{*}$ & $0.61(0.52-0.70)$ \\
\hline \multirow{3}{*}{ Psmb5 } & 0.50 & $1.36(1.29-1.43)^{*}$ & $0.85(0.84-0.87)$ \\
\hline & Control & $1.00(0.93-1.08)$ & $1.00(0.84-1.18)$ \\
\hline \multirow{3}{*}{ Psmc6 } & 0.05 & $1.82(1.56-2.12)^{* *}$ & $0.45(0.37-0.55)$ \\
& 0.50 & $1.61(1.52-1.71)^{* *}$ & $0.66(0.59-0.74)$ \\
\cline { 2 - 4 } & Control & $1.00(0.94-1.07)$ & $1.00(0.90-1.12)$ \\
\cline { 2 - 4 } & 0.05 & $1.72(1.52-1.95)^{* *}$ & $0.79(0.71-0.88)$ \\
\hline
\end{tabular}

$* \mathrm{P}<0.05$ and $* * \mathrm{P}<0.01$ compared to control

Table 5 The effect of styrylcarbatone on Psma3, Psmb5 and Psmc6 gene expression in the kidney and blood

\begin{tabular}{lccc}
\hline & $\begin{array}{c}\text { Styrylcarbatone } \\
(\mathbf{m g} / \mathbf{k g})\end{array}$ & $\begin{array}{c}\text { Kidney } \\
\text { fold difference (SEM range) }\end{array}$ & $\begin{array}{c}\text { Blood } \\
\text { fold difference (SEM range) }\end{array}$ \\
\hline \multirow{3}{*}{ Psma3 } & Control & $1.00(0.93-1.07)$ & $1.00(0.87-1.14)$ \\
\cline { 2 - 4 } & 0.05 & $1.65(1.53-1.79)^{* *}$ & $0.99(0.78-1.26)$ \\
\hline \multirow{3}{*}{ Psmb5 } & 0.50 & $1.53(1.43-1.64)^{* *}$ & $1.13(0.93-1.37)$ \\
\cline { 2 - 4 } & Control & $1.00(0.93-1.08)$ & $1.00(0.84-1.18)$ \\
\hline \multirow{3}{*}{ Psmc6 } & 0.05 & $1.63(1.39-1.90)^{* *}$ & $0.87(0.64-1.18)$ \\
\cline { 2 - 4 } & 0.50 & $1.41(1.36-1.47)^{*}$ & $1.18(0.97-1.44)$ \\
\cline { 2 - 4 } & Control & $1.00(0.94-1.07)$ & $1.00(0.90-1.12)$ \\
\hline & 0.05 & $2.05(1.98-2.13)^{* * *}$ & $1.09(0.90-1.32)$ \\
\hline
\end{tabular}

${ }^{*} \mathrm{P}<0.05,{ }^{* *} \mathrm{P}<0.01$, and ${ }^{* * *} \mathrm{P}<0.0001$ compared to control

proteasome, but did increase the expression of Psmc6, which encodes for the subunit of the 19S regulatory complex. At the higher dose glutapyrone also increased the expression of Psmb5, which codes for the inner ring subunit of the $20 \mathrm{~S}$ proteasome. Interestingly, while AV-153-Na increased Psmb5 expression in the kidney, AV-153-Ca decreased it. Furthermore, AV-153-Ca was the only compound that decreased the expression of any of the tested genes in the kidney.

In the blood, glutapyrone increased only Psmb5 expression. An earlier study (15) reported that glutapyrone increased the mRNA expression of Psma6, another subunit of the outer ring of the 20S proteasome, both in the kidney and blood. Metcarbatone at the higher dose decreased Psmc6 expression in blood.

In the liver, AV-153-Na upregulated the expression of Psma6 and also of Psmc6 at the higher dose but downregulated Psmb5 at the lower dose. The higher dose of AV-153-Ca increased only Psma6 expression.

1,4-DHP derivatives as prospective drugs have already shown antioxidant activities and a wide range of antiaging, antibacterial, anticancer, and neuroprotective actions (10). Glutapyrone, a representative of the novel group of 1,4-DHP derivatives with weak $\mathrm{Ca}^{2+}$ channel blocker activity has very low toxicity and multiple pharmacological properties, including concomitant effects on multiple neurotransmitter systems and antioxidant activities (22). Carbatone, another compound of this group, administered orally, showed fast absorption in the gastrointestinal tract and $62 \%$ bioavailability. It quickly spreads across tissues and is excreted mostly through urine and faeces. This group of 1,4-DHP derivatives seems to have a very low cytotoxicity at the tested doses (unpublished data).

It also seems that the protective antioxidant activities of 1,4-DHP derivatives are achieved by targeting the mitochondria. They might be working through direct scavenging of reactive oxygen species and decomposition of hydrogen peroxide. Furthermore, they stimulate cell growth and differentiation (23). An in vitro study in human osteoblast-like cells treated with 1,4-DHP derivatives (23) demonstrated de novo glutathione synthesis, indicating the involvement of the NRF2 signalling pathway in the action of these compounds. It also suggested that the bioactivity of 1,4-DHP derivatives is associated with 4-hydroxynonenal and related second messengers of free radicals, but precise bioactivity mechanisms remain to be elucidated. The increase in proteasomal gene expression by 1,4-DHP derivatives may have similar beneficial mechanisms as those reported for antioxidants, which elevate transcription levels of $26 \mathrm{~S}$ proteasome subunits responsible for removal of damaged proteins and attenuating the progression of human diseases related to oxidative stress (24). 
Table 6 The effect of glutapyrone on Psma3, Psmb5 and Psmc6 gene expression in the kidney and blood

\begin{tabular}{cccc}
\hline \multirow{3}{*}{ Psma3 } & $\begin{array}{c}\text { Glutapyrone } \\
(\mathbf{m g} / \mathbf{k g})\end{array}$ & $\begin{array}{c}\text { Kidney } \\
\text { fold difference (SEM range) }\end{array}$ & $\begin{array}{c}\text { Blood } \\
\text { fold difference (SEM range) }\end{array}$ \\
\cline { 2 - 4 } & Control & $1.00(0.93-1.07)$ & $1.00(0.87-1.14)$ \\
\hline \multirow{3}{*}{ Psmb5 } & 0.05 & $1.10(0.95-1.26)$ & $1.49(1.27-1.74)$ \\
\cline { 2 - 4 } & 0.50 & $1.21(1.05-1.39)$ & $0.99(0.86-1.14)$ \\
\hline \multirow{3}{*}{ Psmc6 } & Control & $1.00(0.93-1.08)$ & $1.00(0.84-1.18)$ \\
\cline { 2 - 4 } & 0.05 & $1.40(1.26-1.55)$ & $1.04(1.94-2.14)^{*}$ \\
\cline { 2 - 4 } & 0.50 & $1.73(1.49-2.01)^{* *}$ & $1.00(0.90-1.12)$ \\
\cline { 2 - 4 } & Control & $1.00(0.94-1.07)$ & $1.30(1.19-1.42)$ \\
\hline
\end{tabular}

$* \mathrm{P}<0.05$ and $* * \mathrm{P}<0.01$ compared to control

Table 7 The effect of AV-153-Na on Psma3, Psmb5, Psmc6 and Psma6 gene expression in the kidney and liver

\begin{tabular}{|c|c|c|c|}
\hline & $\begin{array}{l}\mathrm{AV}-153-\mathrm{Na} \\
(\mathrm{mg} / \mathrm{kg})\end{array}$ & $\begin{array}{c}\text { Kidneys } \\
\text { fold difference (SEM range) }\end{array}$ & $\begin{array}{c}\text { Liver } \\
\text { fold difference (SEM range) }\end{array}$ \\
\hline \multirow{3}{*}{ Psma3 } & Control & $1.00(0.97-1.03)$ & $1.00(0.95-1.05)$ \\
\hline & 0.05 & $1.28(1.21-1.35)^{*}$ & $0.94(0.82-1.08)$ \\
\hline & 0.50 & $1.28(1.12-1.46)^{*}$ & $1.23(1.19-1.26)$ \\
\hline \multirow{3}{*}{ Psmb5 } & Control & $1.00(0.99-1.02)$ & $1.00(0.94-1.04)$ \\
\hline & 0.05 & $1.64(1.51-1.78)^{* * *}$ & $0.79(0.71-0.87)^{*}$ \\
\hline & 0.50 & $1.68(1.47-1.91)^{* * *}$ & $1.09(1.08-1.11)$ \\
\hline \multirow{3}{*}{ Psmc6 } & Control & $1.00(0.97-1.03)$ & $1.00(0.92-1.09)$ \\
\hline & 0.05 & $1.39(1.29-1.51)^{* *}$ & $1.19(1.07-1.33)$ \\
\hline & 0.50 & $1.47(1.30-1.66)^{* *}$ & $1.61(1.59-1.62)^{*}$ \\
\hline \multirow{3}{*}{ Psma6 } & Control & $1.00(0.92-1.08)$ & $1.00(0.94-1.06)$ \\
\hline & 0.05 & $2.00(1.78-2.25)^{* * *}$ & $1.49(1.32-1.68)^{* *}$ \\
\hline & 0.50 & $2.17(1.87-2.52)^{* * *}$ & $1.91(1.86-1.95)^{* * *}$ \\
\hline
\end{tabular}

$* \mathrm{P}<0.05, * * \mathrm{P}<0.01$, and $* * * \mathrm{P}<0.001$ compared to control

The downregulation of UPS genes in the liver seems to correspond with age. In old mice, this downregulation was reported to lead to the accumulation of $\operatorname{I\kappa B} \alpha$ in the cytoplasm, which prevented the activation of the NF- $\mathrm{KB}$ protein, which is important for hepatocyte survival and liver health (25). Older age also seems to be associated with lower mRNA levels of both proteasome beta subunits, which are directly involved in the proteolytic function of the proteasome and antioxidant activity (26), but some healthy centenarians were reported to have proteasome subunit mRNA levels close to young donors. Furthermore, one study showed that a stable transfection of either PSMB I or PSMB5 enhanced proteasome function and resistance to oxidative stress (27). This is why our findings of increased proteasome subunit gene expression by 1,4-DHP derivatives seem promising in terms of pharmacotherapy.

Downregulated proteasomal gene expression is also associated with several pathologies. For instance, in patients with schizophrenia, dentate granule neurons showed decreased expression of several proteasome subunit and other genes involved in protein processing by proteasomes and ubiquitin, resulting in a deficient ubiquitin-proteasome function that can lead to reduced neuron responsiveness (28). In patients with Parkinson's disease, both catalytic and regulatory subunits of the UPS, including the PSMA3 gene analysed in this study, showed decreased gene expression in substantia nigra (29). This might lead to decreased levels of the $26 \mathrm{~S}$ proteasome complex, insufficient degradation of short-lived proteins such as cyclins, and accumulation of ubiquitinated proteins, which can eventually result in dopaminergic neuronal damage. In this kind of pathologies, the potential of 1,4-DHP derivatives to increase proteasomal gene expression might lead to restored proteasome function and therapeutic effect. However, additional research is needed to determine whether 1,4-DHP derivatives increase proteasomal protein expression in the same way as they increase gene expression.

To sum up, our research has confirmed the ability of several 1,4-DHP derivatives to increase the expression of proteasome subunit genes. This might be a promising property for the development of drugs for conditions associated with impaired proteasomal functions and low mRNA levels of proteasome subunits. 
Table 8 The effect of AV-153-Ca on Psma3, Psmb5, Psmc6 and Psma6 gene expression in the kidney and liver

\begin{tabular}{lccc} 
& $\begin{array}{c}\text { AV-153-Ca } \\
(\mathbf{m g} / \mathbf{k g})\end{array}$ & $\begin{array}{c}\text { Kidney } \\
\text { fold difference (SEM range) }\end{array}$ & $\begin{array}{c}\text { Liver } \\
\text { fold difference (SEM range) }\end{array}$ \\
\cline { 2 - 4 } Psma3 & Control & $1.00(0.97-1.03)$ & $1.00(0.95-1.05)$ \\
\hline \multirow{3}{*}{ Psmb5 } & 0.05 & $0.89(0.76-1.03)$ & $0.96(0.94-0.99)$ \\
\cline { 2 - 4 } & 0.50 & $1.00(0.92-1.09)$ & $0.89(0.81-0.97)$ \\
\hline \multirow{3}{*}{ Psmc6 } & Control & $1.00(0.99-1.02)$ & $1.00(0.94-1.04)$ \\
\cline { 2 - 4 } & 0.05 & $0.62(0.55-0.71)^{* *}$ & $1.05(1.03-1.08)$ \\
\hline \multirow{3}{*}{ Psma6 } & 0.50 & $0.85(0.75-0.95)$ & $0.82(0.71-0.95)$ \\
\cline { 2 - 4 } & Control & $1.00(0.97-1.03)$ & $1.00(0.92-1.09)$ \\
\cline { 2 - 4 } & 0.05 & $0.85(0.77-0.93)$ & $0.89(0.86-0.93)$ \\
\hline
\end{tabular}

$* \mathrm{P}<0.05$ and $* * \mathrm{P}<0.01$ compared to control

\section{Acknowledgements}

This work was supported from the Grant of the Latvian Council of Science 278/2012 and the National Research Program "Biomedicine 2014".

\section{Conflicts of interest}

The authors declare that they have no conflict of interest.

\section{REFERENCES}

1. Klaips CL, Jayaraj GG, Hartl FU. Pathways of cellular proteostasis in aging and disease. J Cell Biol 2018;217:51-63. doi: $10.1083 /$ jcb.201709072

2. Albornoz N, Bustamante H, Soza A, Burgos P. Cellular responses to proteasome inhibition: molecular mechanisms and beyond. Int J Mol Sci 2019;20(14):3379. doi: 10.3390/ ijms20143379

3. Motosugi R, Murata S. Dynamic regulation of proteasome expression. Front Mol Biosci 2019;6:30. doi: 10.3389/ fmolb.2019.00030

4. Marshall RS, Vierstra RD. Dynamic regulation of the $26 \mathrm{~S}$ proteasome: from synthesis to degradation. Front Mol Biosci 2019;6:40. doi: 10.3389/fmolb.2019.00040

5. Sherman DJ, Li J. Proteasome inhibitors: harnessing proteostasis to combat disease. Molecules 2020;25(3):671. doi: 10.3390/molecules25030671

6. Coleman RA, Trader DJ. Methods to discover and evaluate proteasome small molecule stimulators. Molecules 2019;24(12):2341. doi: 10.3390/molecules24122341

7. Dammann P. Slow aging in mammals - Lessons from African mole-rats and bats. Semin Cell Dev Biol 2017;70:154-63. doi: 10.1016/j.semcdb.2017.07.006

8. Cuanalo-Contreras K, Moreno-Gonzalez I. Natural products as modulators of the proteostasis machinery: implications in neurodegenerative diseases. Int J Mol Sci 2019;20(19):4666 doi: 10.3390/ijms20194666

9. Zhang Y, Loh C, Chen J, Mainolfi N. Targeted protein degradation mechanisms. Drug Discov Today Technol 2019;31:53-60. doi: 10.1016/j.ddtec.2019.01.001
10. Velena A, Zarkovic N, Gall Troselj K, Bisenieks E, Krauze A, Poikans J, Duburs G. 1,4-Dihydropyridine derivatives: dihydronicotinamide analogues-model compounds targeting oxidative stress. Oxid Med Cell Longev 2016;2016:1892412. doi: 10.1155/2016/1892412

11. Bruvere I, Bisenieks E, Poikans J, Uldrikis J, Plotniece A, Pajuste K, Rucins M, Vigante B, Kalme Z, Gosteva M, Domracheva I, Velena A, Vukovic T, Milkovic L, Duburs G, Zarkovic N. Dihydropyridine derivatives as cell growth modulators in vitro. Oxid Med Cell Longev 2017;2017:4069839. doi: 10.1155/2017/4069839

12. Leonova E, Rostoka E, Sauvaigo S, Baumane L, Selga T, Sjakste N. Study of interaction of antimutagenic 1,4-dihydropyridine AV-153-Na with DNA-damaging molecules and its impact on DNA repair activity. PeerJ 2018;6:e4609. doi: 10.7717/peerj.4609

13. Leonova E, Ošiņa K, Duburs G, Bisenieks E, Germini D, Vassetzky Y, Sjakste N. Metal ions modify DNA-protecting and mutagen-scavenging capacities of the AV-153 1,4-dihydropyridine. Mutat Res 2019;845:403077. doi: 10.1016/j.mrgentox.2019.06.007

14. Ošiņa K, Rostoka E, Isajevs S, Sokolovska J, Sjakste T, Sjakste N. Effects of an antimutagenic 1,4-dihydropyridine AV-153 on expression of nitric oxide synthases and DNA repair-related enzymes and genes in kidneys of rats with a streptozotocin model of diabetes mellitus. Basic Clin Pharmacol Toxicol 2016;119:458-63. doi: 10.1111/ bcpt. 12617

15. Ošiņa $\mathrm{K}$, Leonova $\mathrm{E}$, Isajevs $\mathrm{S}$, Baumane $\mathrm{L}$, Rostoka $\mathrm{E}$, Sjakste T, Bisenieks E, Duburs G, Vīgante B, Sjakste N. Modifications of expression of genes and proteins involved in DNA repair and nitric oxide metabolism by carbatonides [disodium-2,6-dimethyl-1,4- dihydropyridine-3,5bis(carbonyloxyacetate) derivatives] in intact and diabetic rats. Arh Hig Rada Toksikol 2017;68:212-27. doi: 10.1515/ aiht-2017-68-2945

16. Ošina K, Rostoka E, Sokolovska J, Paramonova N, Bisenieks E, Duburs G, Sjakste N, Sjakste T. 1,4-dihydropyridine derivatives without $\mathrm{Ca}^{2+}$-antagonist activity up-regulate Psma6 mRNA expression in kidneys of intact and diabetic rats. Cell Biochem Funct 2016;34:3-6. doi: 10.1002/cbf.3160 
17. Council of Europe. European Convention for the Protection of Vertebrate Animals Used for Experimental and other Scientific Purposes [displayed 31 May 2021]. Available at https://www.coe.int/en/web/conventions/full-list/-/ conventions/treaty/123

18. Ye J, Coulouris G, Zaretskaya I, Cutcutache I, Rozen S, Madden TL. Primer-BLAST: A tool to design target-specific primers for polymerase chain reaction. BMC Bioinformatics 2012;13:134. doi: 10.1186/1471-2105-13-134

19. Sokolovska J, Isajevs S, Sugoka O, Sharipova J, Lauberte L, Svirina D, Rostoka E, Sjakste T, Kalvinsh I, Sjakste N. Correction of glycaemia and GLUT1 level by mildronate in rat streptozotocin diabetes mellitus model. Cell Biochem Funct 2011;29:55-63. doi: 10.1002/cbf.1719

20. Pfaffl MW, Tichopad A, Prgomet C, Neuvians TP. Determination of stable housekeeping genes, differentially regulated target genes and sample integrity: BestKeeperExcel-based tool using pair-wise correlations. Biotechnol L e t t $2004 ; 26: 509-15$. d o i : 10.1023/b:bile.0000019559.84305.47

21. Taylor SC, Nadeau K, Abbasi M, Lachance C, Nguyen M, Fenrich J. The ultimate qPCR experiment: producing publication quality, reproducible data the first time. Trends Biotechnol 2019;37:761-74. doi: 10.1016/j. tibtech.2018.12.002

22. Caputi FF, Carboni L, Mazza D, Candeletti S, Romualdi P. Cocaine and ethanol target $26 \mathrm{~S}$ proteasome activity and gene expression in neuroblastoma cells. Drug Alcohol Depend 2016;161:265-75. doi: 10.1016/j.drugalcdep.2016.02.012

23. Misane I, Klusa V, Dambrova M, Germane S, Duburs G, Bisenieks E, Rimondini R, Ogren SO. "Atypical" neuromodulatory profile of glutapyrone, a representative of a novel 'class' of amino acid-containing dipeptide-mimicking 1,4-dihydropyridine (DHP) compounds: in vitro and in vivo studies. Eur Neuropharmacol 1998;8:329-47. doi: 10.1016/ s0924-977x(97)00097-7

24. Milkovic L, Vukovic T, Zarkovic N, Tatzber F, Bisenieks E, Kalme Z, Bruvere I, Ogle Z, Poikans J, Velena A, Duburs G. Antioxidative 1,4-dihydropyridine derivatives modulate oxidative stress and growth of human osteoblast-like cells in vitro. Antioxidants (Basel) 2018;7(9):123. doi: 10.3390/ antiox 7090123

25. Kwak MK, Wakabayashi N, Greenlaw JL, Yamamoto M, Kensler TW. Antioxidants enhance mammalian proteasome expression through the Keap1-Nrf2 signaling pathway. Mol Cell Biol 2003;23:8786-94. doi: 10.1128/MCB.23.23.87868794.2003

26. Huber N, Sakai N, Eismann T, Shin T, Kuboki S, Blanchard J, Schuster R, Edwards MJ, Wong HR, Lentsch AB. Agerelated decrease in proteasome expression contributes to defective nuclear factor-kappaB activation during hepatic ischemia/reperfusion. Hepatology 2009;49:1718-28. doi: 10.1002/hep. 22840

27. Chondrogianni N, Petropoulos I, Franceschi C, Friguet B, Gonos ES. Fibroblast cultures from healthy centenarians have an active proteasome. Exp Gerontol 2000;35:721-8. doi: 10.1016/s0531-5565(00)00137-6

28. Chondrogianni N, Stratford FL, Trougakos IP, Friguet B, Rivett AJ, Gonos ES. Central role of the proteasome in senescence and survival of human fibroblasts: induction of a senescence-like phenotype upon its inhibition and resistance to stress upon its activation. J Biol Chem 2003;278:2802637. doi: $10.1074 /$ jbc.M301048200

29. Altar CA, Jurata LW, Charles V, Lemire A, Liu P, Bukhman Y, Young TA, Bullard J, Yokoe H, Webster MJ, Knable MB, Brockman JA. Deficient hippocampal neuron expression of proteasome, ubiquitin, and mitochondrial genes in multiple schizophrenia cohorts. Biol Psychiatry 2005;58:85-96. doi: 10.1016/j.biopsych.2005.03.031

30. Grünblatt E, Mandel S, Jacob-Hirsch J, Zeligson S, Amariglo N, Rechavi G, Li J, Ravid R, Roggendorf W, Riederer P, Youdim MBH. Gene expression profiling of parkinsonian substantia nigra pars compacta; alterations in ubiquitinproteasome, heat shock protein, iron and oxidative stress regulated proteins, cell adhesion/cellular matrix and vesicle trafficking genes. J Neural Transm 2004;111:1543-73. doi: $10.1007 / \mathrm{s} 00702-004-0212-1$

\section{1,4 dihidropiridinski derivati povećavaju ekspresiju gena Psma3, Psmb5 i Psmc6 u glasničkoj RNA štakora}

Ubikvitin-proteasomski sustav utječe na različite funkcije bjelančevina i stanica. Poremećaji u njegovoj regulaciji mogu dovesti do poremećaja u proteostazi koji su povezani s nastankom različitih bolesti i sa starenjem, ali se sustav može regulirati u liječenju pojedinih bolesti lijekovima poput 1,4 dihidropiridinskih (1,4 DHP) derivata, koji štite živčani sustav i usporavaju starenje. Cilj ovoga istraživanja bio je utvrditi djelovanje nekoliko 1,4 DHP derivata na ekspresiju glasničke RNA (mRNA) u proteasomskim genima Psma3, Psmb5 i Psmc6 u više štakorskih organa. Stakori su tri dana dobivali oralne doze metkarbatona, etkarbatona, glutapirona, stirilkarbatona, AV-153-Na ili AV-153-Ca, a genska se ekspresija u mRNA utvrdila polimeraznom lančanom reakcijom u stvarnom vremenu (engl. real-time polymerase chain reaction, krat. PCR). Osim toga, utvrdili smo djelovanje derivata AV-153-Na i AV-153-Ca na ekspresiju gena Psma6. U bubrezima su metkarbaton, etkarbaton, stirilkarbatoni AV-153-Na povećali ekspresiju svih analiziranih gena. Glutapiron je povećao ekspresiju Psmb5 i Psmc6, ali ne i Psma3. U krvi je glutapiron povećao gensku ekspresiju Psmb5. U jetrima je AV-153-Na povećao ekspresiju Psma6 i Psmc6, istodobno smanjivši ekspresiju Psmb5. AV-153-Ca utjecao je samo na Psma6, povećavši mu ekspresiju. Sposobnost 1,4-DHP derivata da povećaju gensku ekspresiju proteasomskih podjediničnih proteina obećava u smislu mogućnosti liječenja bolesti povezanih s poremećenom proteasomskom funkcijom, no nužna su daljnja istraživanja.

KLJUČNE RIJEČI: AV-153-Ca; AV-153-Na; etkarbaton; glutapiron; metkarbaton; stirilkarbaton; poremećena proteasomska funkcija; proteasomske podjedinice; ubikvitin-proteasomski sustav 